\title{
Language as a Marker of Identity in Tiaret Speech Community
}

\author{
Brahmi Mohamed*, Mahieddine Rachid, Bouhania Bachir \\ Department of English, Faculty of Arts and Languages, University of Adrar, Algeria
}

Copyright $(2019$ by authors, all rights reserved. Authors agree that this article remains permanently open access under the terms of the Creative Commons Attribution License 4.0 International License

\begin{abstract}
This paper explores the linguistic behavior in relation to the identity of speakers who stay in their hometown and speakers who travel from one dialect region to another. Following the methodology of sociolinguistic variation studies, combined with qualitative analyses, this study examines two noticeable linguistic features of Tiaret compared to those acquired by speakers who moved to other dialect areas. Qualitative analyses of speakers' social identities, attitudes and language practices match quantitative analyses of patterns of phonological variation. The study finds that the migrant groups do make changes in their linguistic production due to their continuous exposure to a new dialect. Moreover, the findings suggest that speakers' linguistic behavior is noticeably related to their identities, social networks, language attitudes and the wider sociopolitical framework in the whole country.
\end{abstract}

Keywords Identity, Phonological Variation, Linguistic Behavior, Language Practices

\section{Introduction}

Ever since Labov's (1963) early studies, sociolinguists have considered language attitudes as one of the major factors manipulating language variation and change. Implementing recent approaches to variation combined with qualitative inquiry, this study explores the linguistic behavior and language ideologies of speakers who stayed in their hometown and those who migrated from one dialect to another in the sociocultural context of contemporary Algeria.

Current developments in the field of sociolinguistic variation view variation as a reflection of social agency that constructs social meaning and considering how ideologies cooperate with internal linguistic restraints on variation (Milroy 2004).

In his book Dialects in Contact, Trudgill (1986) examines factors of long-term linguistic accommodation by speakers moving to a different region from their own.
In his analysis of British English speakers who reside in the USA, Trudgill suggests that how, the extent to which, and why accommodation to American English occurs appears to be due to several factors such as phonological contrast and strength of stereotyping. Adopting insights from these researchers, as well as taking language ideologies into consideration, this study suggests factors that trigger or fail to trigger accommodation by speakers migrating to a new dialect area.

Previous sociolinguistic research has detailed how historical, political and sociolinguistic factors have influenced issues of language, identity, and conflicts in almost every country and in Algeria particularly, as stated by (Benrabah, 2007) in his The Language Planning Situation in Algeria. Those studies have largely stressed language use in the larger macro social structure, focusing on language attitudes, language shift, and language use.

\section{Language Variation and Change}

Language is defined as a system of doubly articulated signs, that is to say that the meaning-making is done at two levels of articulation: that of significant entities (Morphemes and lexemes) forming statements and that of distinctive units (phonemes) forming the signifying units. Since Ferdinand Saussure, one also distinguishes, the language and the word, which is the use and the realization of the system of language by its speakers, as for language, it is the human faculty implemented by means of language.

Speakers of commonly comprehensible dialects interact and converse with each other, the dialects that are in contact may be changed linguistically. When speakers of a particular dialect are exposed to another dialect in the long term, such as in the case of migration, these speakers may adjust their speech to accommodate to the members of local speech community and modify their pronunciation of certain linguistic variables that are markers within the local community (Trudgill 1986). Gradually, they acquire a dialect other than their native dialect. 
Language guarantees the social cohesion of the community that speaks it, while becoming the container and place of social integration, literacy and acculturation; it is also necessary to remember that it creates solidarity with the past and history through the discourses carried by this language; that is, one must associate the discourses and the culture, if not how to explain that the Maghreb and French cultures are not identical despite the use of the same language (French or Arabic)

Another example of this situation can be borrowed from Berber speakers who live in the non-Berber regions of Algeria where they use three different languages: Berber, Algerian and French, changing from one language to another or mixing them, more often in the same language. This results from their acquisition of the rules and rules of language use within these communities. In this regard, Gumperz, (1968:69) claims that a discourse community is one, all those whose members share at least one unique variety and standards for its appropriate use.

\section{Speech Accommodation Theory}

In order to reach intelligibility and communicative efficiency, speakers may shift styles mainly in response to their audience; they regulate their speech towards their listeners if they wish to express or achieve solidarity. This approach is rooted in a social psychological approach to stylistic variation originally known as speech accommodation theory (Giles 1973).

The theory talks about speakers intending to depict their positive identity to others. They tend to match their own vocabulary, accent and cadence as of other listeners. For instance, people adopt the slang their friends use to fit in. People talk differently using different words and gestures accordingly to the different group of people like old people, children, women, men, teens, rich, poor, powerful, weak, etc.

Sociolinguists believe that speech accommodation began as "a socio- psychological model of speech-style modifications". It then developed into communication accommodation theory in order to acknowledge that not only speech but other "communicative behavior" (Giles et al., 2007:134), affect interpersonal or intergroup interaction, i.e. an individual's speaker identity is constructed from interaction with varying social groups. Each group constitutes a unique culture and social category. An individual's membership of a social group will typically influence the individual's linguistic choice. The individual will be a member of a group because he wishes to be part of the group. That is to say, in order to minimize the social distance between that individual and the group he wishes to be part of, he will then have to reduce the linguistic intergroup differences.

Accommodation process has been further divided into two categories according to this theory. One of them is convergence, which is a process of people naturally tending to adapt other communicators' way of communicating to connect and decrease their social differences. The other one is divergence, which is a process of non-adaptation of communication characteristics and accentuation of social and nonverbal communication differences.

The people involved and situation of communication decide which accommodation process is used. If a person is interacting with another with very high standards, better at things and who seem to be powerful, then divergent characteristics are shown highlighting the differences. Similarly, if the other person is perceived to be of same standard, people try to be like them creating a comfort zone for both.

\section{Method}

\section{Data Collection}

The research method employed in this paper is the Labovian Method that distinguished mainly between two categories of variables: linguistic; morphological, lexical and phonological, and the social variables named; age, gender and social class. In order to collect the data, we have opted for analyzing only the phonological variables as we think they noticeably mark many speakers' attitudes and identities in the city of Tiaret. The wilaya of Tiaret is located in the north-west of the country. Geographically speaking, the city is bounded by several wilayas which makes it a heterogenous area of sociolinguistic research as it is considered as the meeting point where other linguistic landscapes inevitably make constant contact.

Two main groups are dealt with in the present paper; speakers staying in their hometown, and those moving to another dialect area or district. To better-cover the research objectives, we have limited the sample and chosen university students to conduct the interviews. Fifty (50) local speakers spent their university career in Tiaret, and the same number (50) migrants who moved to Mostaganem University have carried on their studies and stayed in campus the whole university period.

The speakers' speech data were gathered using sociolinguistic semi-structured interviews. Interviews are seen as the most commonly adopted approach among sociolinguists to elicit the spontaneous vernacular usage of speakers (Milroy \& Gordon 2003). The conversations lasted about half an hour for the individual interviews and about an hour and a half for the group interviews. We have aimed at interviewing students to gain access to their vernacular speech and the primary interest of the interviews is to provoke natural conversational speech. We included questions to hit upon topics that interest the interviewees. 


\section{Results}

\section{Phonological Variables: Local Students vs. Migrant Students}

Variables that have been our focus in this research, are the two fricative sounds [ð], [ $\theta]$ and the plosive [d'], as realized by speakers of Tiaret community who stayed in their home town, compared to those who moved and spent years in Mostaganem University. The sounds [ $\theta]$, as in /Өlæ $\theta$ ə/ means, 'three', [ð] as in /ðbi:Xə/ means 'slaughtering', and the sound [d'] as in /d'arwək/ means 'now'. The three examples are pronounced in Classical

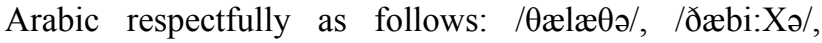
/el'æn/.

As our findings show, $(90 \%)$ of the local speakers fully pronounce the three sounds without any difficulty. On the other hand, $(40 \%)$ of migrant students have noticeably preferred, during the conversations led by the researcher, to replace the sounds with completely different ones as shown in the following chart:

Table 1. Consonantal Variation: Local Students vs. Migrant Students

\begin{tabular}{|c|c|c|c|}
\hline \multicolumn{2}{|c|}{$\begin{array}{l}\text { Words as locally } \\
\text { pronounced }\end{array}$} & \multirow{2}{*}{$\begin{array}{c}\begin{array}{c}\text { Words realized } \\
\text { by migrant } \\
\text { students }\end{array} \\
\text { /dbi:Xə/ } \\
\text { /də'ri/,/dræri/ } \\
\text { /dæk/ }\end{array}$} & \multirow{2}{*}{$\begin{array}{c}\text { Meaning } \\
\text { Slaughtering } \\
\text { Child, Children } \\
\text { That; like in 'that } \\
\text { day' }\end{array}$} \\
\hline [ð] & $\begin{array}{c}\text { - /ðbi:Xə/ } \\
\text { - /ðə'ri/, /ðræri/ } \\
\text { - /ðæk/ }\end{array}$ & & \\
\hline$[\theta]$ & 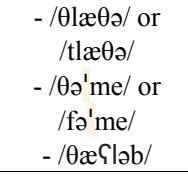 & $\begin{array}{l}\text { /tlætə/ } \\
\text { /ta'me/ } \\
\text { /tæSləb/ }\end{array}$ & $\begin{array}{c}\text { Three } \\
\text { There (place) } \\
\text { Fox (animal) }\end{array}$ \\
\hline$\left[\mathrm{d}^{\prime}\right]$ & $\begin{array}{l}\text { - /d'arwək/ } \\
\text { - /d'arbo/ } \\
\text { - /d'al/ }\end{array}$ & $\begin{array}{c}\text { /darwok/ } \\
\text { /darbeh/ } \\
\text { /dal/ }\end{array}$ & $\begin{array}{c}\text { Now } \\
\text { He hit him } \\
\text { Shadow }\end{array}$ \\
\hline
\end{tabular}

The table clearly shows that migrant speakers have adopted completely new sounds and have been influenced by the dialect area they moved to. The phonological features of Mostaganem dialect is seen as different from that of Tiaret. According to $70 \%$ of our participants believe that the sounds: $[ð],[\theta]$ and [d'] are considered as the most difficult to pronounce in Mostaganem dialect. However, the case in Tiaret dialect is different. We have noticed a certain richness at the level of sound realization and articulation. Almost all sounds in the old Classical Arabic phonological system are properly pronounced by local speakers of Tiaret community, whereas the three sample sounds we opted for are not pronounced at all in Mostaganem dialect except by little population. Instead, they are replaced by other sounds as shown in the table below;

Table 2. Sound Change Chart

\begin{tabular}{|c|c|c|}
\hline $\begin{array}{c}\text { Variables according to } \\
\text { general Arabic } \\
\text { phonology }\end{array}$ & $\begin{array}{c}\text { As realized by } \\
\text { local students }\end{array}$ & $\begin{array}{c}\text { As realized by } \\
\text { migrant students }\end{array}$ \\
\hline$[ð]$ & {$[ð]$} & {$[\mathrm{d}]$} \\
\hline$[\theta]$ & {$[\theta]$} & {$[\mathrm{t}]$} \\
\hline$[\mathrm{d}]$ & {$\left[\mathrm{d}^{\prime}\right]$} & {$[\mathrm{d}]$ or $[\mathrm{D}]$} \\
\hline
\end{tabular}

As shown in the chart above, according to the results gathered from the interviews, migrant students change the pronunciation of the three sounds even in their hometown Tiaret with local speakers. When we asked them about the reason, we have noticed that the informants were clearly split into two groups; two points of view. The first group, which represented almost 60 percent, answered that they did that consciously and favored it to mark the separating line between them and those who stayed in their hometown. They added, during the conversation, "We want to show that moving to another town to study means more than just getting a degree. It's acquiring a whole different culture and lifestyle..." The second group represented somehow the conservatives; those who preferred sticking to their accent because, as they believe, it marks their identity and shows their belongings which they stressed how proud they are about them.

Though it was not the purpose of the present research, the findings also show that young speakers are more convergent than their elder counterparts as they tend to avoid the traditional forms and use new forms to make their own speech specific to youth. In addition, male students are more likely to use the standard form than females and tend to be more accommodating to other dialects, as they are more exposed to contact situation with non-local speakers.

\section{Discussion}

In Algeria, with the existence of more than one code due to colonization, the linguistic situation becomes more intricate as the Algerian speakers switch from one language to another (French and Arabic), or mix the two languages at the same time. Such a phenomenon is a speech behavior that has led to a complex Algerian situation occurring as an outcome of language contact. 
Our concern in this study was to focus on the reasons why migrant students tend to avoid keeping Tiaret linguistic features. As far as phonology is concerned, we are interested in the examination of three linguistic variables: $[ð],[\theta]$ and [d']. In spite of the fact that sounds are considered a part of the characteristic features of Tiaret speech, our observation has shown that most migrant students, especially those who spent more than four (4) years in Mostaganem, say that they intentionally change the pronunciation of $[\delta],[\theta]$ and $\left[\mathrm{d}^{\prime}\right]$ as [d], [t] and [D] because they preferred to look different from those students staying in their home university.

The phonological variation in Algerian towns and districts can be seen as a marking geography and a map of linguistic identity of each dialect area. Speakers avoid these stigmatized features not only when speaking to non-local people, but also with family or with friends in their daily conversations. So from such behavior we can say that some Tiaretian linguistic items are lost and this can be explained through the degree of stigmatization of the linguistic item and the speakers' attitudes.

Language is a heterogeneous system of communication; variation has a direct impact on all languages as members of any society differ in terms of social variables such as age, gender and the level of education. Moreover, languages are also affected by change because of the many extra linguistic factors which can be political, social and economic. Our investigations have shown that the speech community of Tiaret has been affected by a number of social and external pressures, thus promoting language variation which in turn leads to language change. The motivation of language change can be introduced from other language systems or in relation to social attribute. It can also be described through mutual contact and speech accommodation processes.

Through our analysis, we have come up with the result that the speaker's intention behind the use of certain linguistic features is due to personal motives in addition to psychological matters, and this phenomenon studied by sociolinguists is called language attitudes, and it is defined as the speaker's reaction or feeling towards language, which can be either their own language variety or the language varieties or languages of others.

\section{Conclusions}

With regard to the results, the study has shown that speakers 'choices between the different variants are dominantly constrained by social factors rather than linguistic factors and that the migrant speakers' overall rate, for example, of substitution of [d] and [ð] is mainly due to social factors and speakers' attitudes and own choice rather than linguistic factors. The results suggest that the social history of the linguistic features and the speakers plays an important role in patterns of linguistic variation; thus, it inevitably leads to language change.

The linguistic landscape in Algeria, and Tiaret in particular, is no more than an offshoot of the historical existence of many languages and cultures who passed by the country throughout a long history. It is quite impossible to cover the whole region and study all its linguistic features one by one but, we have tried to provide the reader with a cursory practical theory about Algerian linguistic historical journey and the current linguistic landscape.

To wrap it all up, no one can deny the fact that language variation goes hand in hand with the speaker's identity, attitude and ideology. The phonological variation in any speech community has become a marker of speakers' identity and social status. Speakers who move to another town and dialect area should be considered as a raw material in the study of language change and variation, as they manifest to create new countless linguistic data.

\section{REFERENCES}

[1] Benrabah, M. (2007). The language planning situation in Algeria. In A. Kaplan, R. B., \& B.

[2] Chambers, J. K, Trudguill. P and Schilling- Estes, N. (2004). The Handbook of Language Variation and Change. Oxford: Blackwell Publishing Ltd.

[3] Coupland, Nicholas (2007). Style: Language Variation and Identity. Cambridge: Cambridge University Press.

[4] Coupland, Nicholas (2001a). Dialect stylization in radio talk. Language in Society 30, 345-375.

[5] Coupland, Nikolas (2001b). Language, situation, and the relational self: theorizing dialect-style in sociolinguistics. In Penelope Eckert \& John R. Rickford (eds.), Style and Sociolinguistic Variation, 185-210. Cambridge: Cambridge University Press.

[6] Dendane, Z. (2007). Sociolinguistic Variation and Attitudes towards Language Behaviour in an Algerian Context. The Case of Tlemcen Arabic. Unpublished Doctorate Thesis. Oran University.

[7] Duranti, A. (1997). Linguistic Anthropology. Cambridge: Cambridge University Press.

[8] Eckert, Penelope (1989). Adolescent social structure and the spread of linguistic change. Language in Society

[9] Eckert, Penelope (2000). Linguistic Variation as Social Practice: The Linguistic Construction of Identity in Belten High. Oxford: Blackwell.

[10] Evans, Betsy (2004). The role of social network in the acquisition of local dialect norms by Appalachian migrants. Language Variation and Change 16, 153-167.

[11] Fought, C. (2004). Sociolinguistic Variation: Critical Reflections. New York. Oxford University Press.

[12] Gumperz, J.J. (1968). "The Speech Communiy”. Giglioli, P. P. (1972). Language and Social Context. Harmondsworth, 
England: Penguin books. 219- 231.

[13] Labov, William (1966). The Social Stratification of English in New York City. Washington, DC: Center for Applied Linguistics.

[14] Labov, William (1969). The logic of nonstandard English. In J. E. Alatis (ed.), Georgetown monographs on language and linguistics 22, 1-44. Washington, DC: Georgetown University Press.

[15] Liao, Silvie Sze-wei (2008). A perceptual dialect study of Taiwan Mandarin: Language attitudes in the era of political battle. The Proceedings of the 20th North American Conference on Chinese Linguistics, 391-408. Columbus, Ohio.

[16] Milroy, Lesley \& Gordon, Matthew (2003). Sociolinguistics: Method and Interpretation. Oxford: Blackwell.

[17] Milroy, Lesley (2004). Language ideologies and linguistic change. In Carmen Fought (ed.), Sociolinguistic variation: Critical reflections 161-177. New York: Oxford University Press.

[18] Trudgill, Peter (1986). Dialects in Contact. Oxford: Blackwell.

[19] Watson, J.C.E. (2002). The Phonology and Morphology of Arabic. New York: Oxford University Press. 